\title{
SEQUESTERED SPACES AND DEFECTIVE DOORS IN TALES BY COLLINS AND RIDDELL
}

Ilse M. Bussing

Universidad de Costa Rica

\begin{abstract}
In nineteenth-century texts the Victorian home is not merely a setting for supernatural activity-it is the protagonist. This article considers how architecture engendered and shaped haunted space within Gothic texts by focusing on a single featurethe door-whose symbolic charge has been widely discussed by critics. However, instead of focusing on psychoanalytic or feminist notions commonly attached to this element, this article considers architectural manuals of the day in order to "read" spatial and cultural implications of the door in Victorian households, arguing that an excessive concern for privacy and concealment in life translates easily into Gothic fiction, in the form of spatial anxiety and infiltration. The discussion centers on two literary texts: The Dead Secret (1857) by Wilkie Collins and The Open Door by Charlotte Riddell (1882).
\end{abstract}

Keywords: Gothic, literature, architecture, Victorian house.

\begin{tabular}{|l|l|l|l|l|}
\hline Ilha do Desterro & Florianópolis & $n^{\circ} 62$ & p. 99- 125 & jan/jun 2012 \\
\hline
\end{tabular}


In early Gothic works of the eighteenth century, medieval architectural sites were crucial elements of setting, generally addressing issues of excess and transgression. In nineteenthcentury texts, the house replaces the castle, generating new spatial and theoretical considerations. The Victorian home is not merely a setting for supernatural activity-it is the protagonist. ${ }^{1}$ This article considers not only how the concepts of home and domesticity generated numerous nineteenth-century texts in which the house was fundamental, but more importantly, how architecture engendered and shaped haunted space within Gothic texts. This discussion focuses on architectural features in the Victorian homemainly the room and the door-whose symbolic charge has been widely discussed in Gothic criticism. However, instead of raising psychoanalytic or feminist notions commonly attached to these features, ${ }^{2}$ this article considers architectural manuals of the day in order to "read" the design and cultural implications of these elements in Victorian households and to see how an excessive concern for privacy and concealment translate easily into Gothic texts in the form of spatial anxiety and infiltration. The discussion will center on two literary texts, The Dead Secret (1857) by Wilkie Collins and "The Open Door" by Charlotte Riddell (1882).

\section{The British Victorian Home and its Gothic Potential}

One cannot speak of "the" Victorian home, since the nineteenth century witnessed such diversity in architectural and ornamental styles that soon exploded into a full-blown "Battle of the Styles." Scottish architect Robert Kerr first employed this colorful phrase to refer to the aesthetic phenomenon which Britain and parts of 
Europe underwent during the nineteenth century. However, despite this stylistic excess, once can still refer to a general layout shared by most middle-class Victorian houses, the type of household that we will look at closely here. Most sources agree that the plan for this home derives from a single source-the large country estate: "English residential needs are embodied most fully in the large country-house [...] the primal, basic form of the English house" (Muthesius 81). Furthermore, the Victorian home was divided into two main areas: that of the family, and that of the servants. The family departments consisted of day-rooms (reception rooms), bedrooms, and children's rooms, among others. The servant rooms included the areas related to the kitchen, the servants' bedrooms, and in larger dwellings, specialized quarters, such as the laundry offices and the bakery. Even though the servants belonged to the lower rung of the social ladder, the areas they used and frequented were as specific and delimited as those for the family. Nun-Appleton in Yorkshire is an example of how complex the domestic layout could become in the homes of the upper spheres of society, or in a "gentleman's house." When observing the plan below, one must keep in mind that it merely illustrates the ground floor, excluding other levels of the immense home. 
102 Ilse M. Bussing, Sequestered Spaces and Defective Doors in...

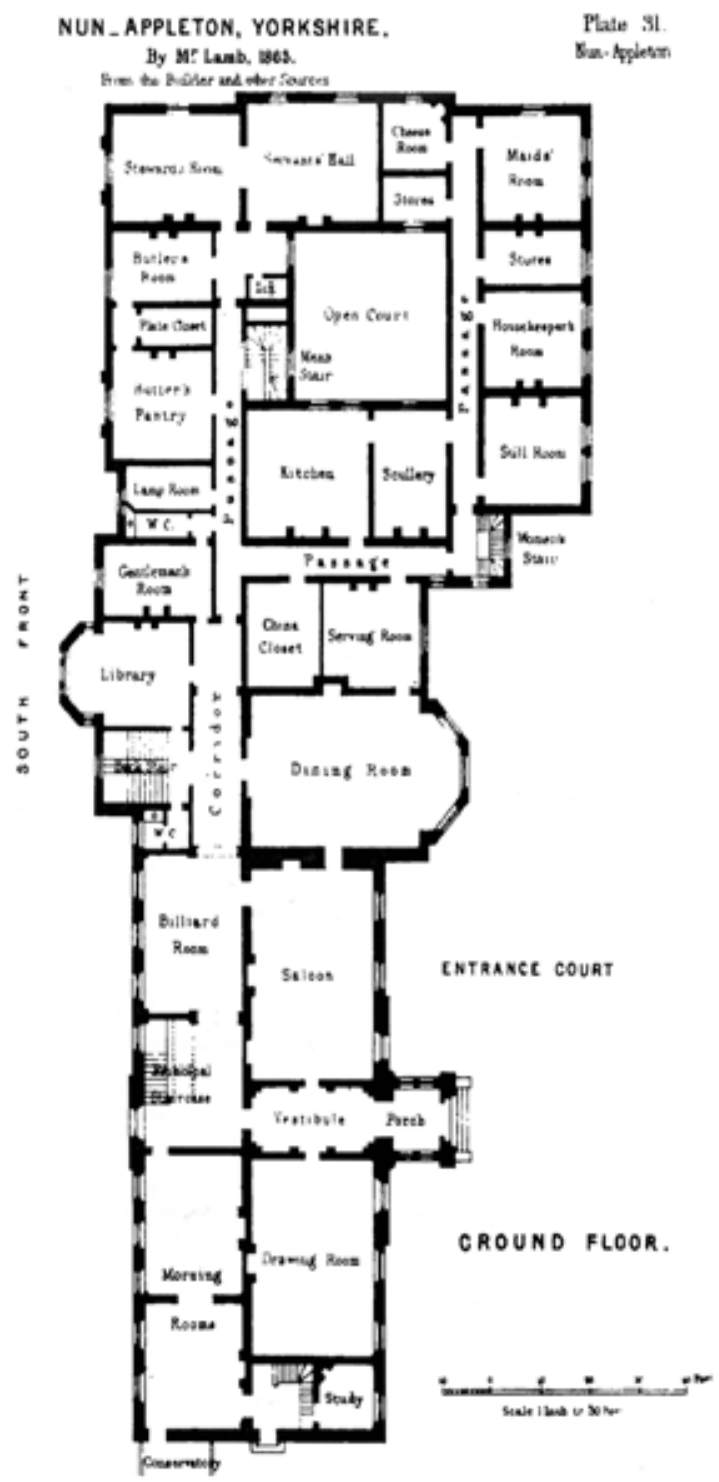

Fig. 1. Ground floor plan of a large "Gentleman's House." Nun-Appleton, Yorkshire, in Robert Kerr, The Gentleman's House. $2^{\text {nd }}$ ed. (London: John Murray, 1865; print; plate 31). 
Even when homeowners could not afford grandiose domestic layouts like the one above, they aspired to homes that were shaped by the same basic tenets of privacy and morality. Even the smallest of middle-class dwellings strived to have a back staircase for the exclusive use of the servants. In the house below, for example, this back staircase originates from the scullery/kitchen area, leading up to the servants' bedroom; despite the proximity between the family chambers and those of the servants, it was deemed necessary to provide not only a separate staircase, but also to seal off any connection between the two groups by placing a party-wall between both areas.
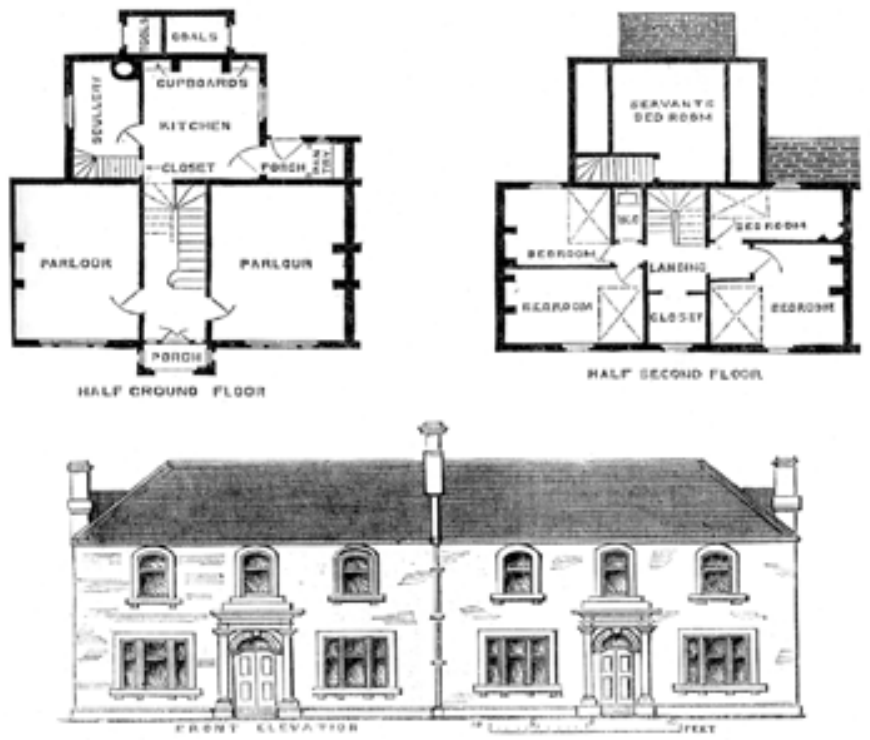

Fig. 2. Design for small houses, 1882, in Helen Long, Victorian Houses and their Details (Oxford: Architectural Press, 2002; print 115) 
In addition to reflecting class divisions, or the "upstairs" and "downstairs" worlds, the Victorian house reflected the roles alloted to the main members of the family, according to their gender and rank. ${ }^{3}$ Thus, the father was often granted the library, which highlighted his intellectual supremacy over the rest of the household and his right to remain isolated from the rest. Since the wife/mother was responsible for the smooth running of domestic work, she would often employ the morning or breakfast-room in order to instruct servants and deal with correspondence, and the drawing room to attend to her social commitments. Last but not least, children, the future of the family, acquired a new importance in the Victorian household. The wealthiest of homes had a day, a night nursery, and a separate schoolroom, proving that the most ideal domestic situation offered a greater degree of spatial distinction. The Victorian home, large or small, was a carefully orchestrated site, where space was delimited according to class and gender, leaving little to chance or improvisation and providing a fertile ground for Gothic tales which took advantage of this spatial rigidity and of the anxiety and division that it often generated.

Gothic fiction profited from internal partitions and boundaries within the house, as well as from the home's withdrawn demeanor in terms of the rest of the world. ${ }^{4}$ The type of household and its internal dynamics had begun shifting much earlier in various cities in Europe with the rise of a wealthier merchant class. After the Renaissance, there was a gradual but clear tendency towards a new type of home that rejected openness in favor of privacy. By the seventeenth century, European town dwellers were becoming increasingly wealthier, and this promoted a separation between the family and economic spheres, thus removing commercial activity from the home. This disentanglement of the means of production from family 
life culminated with the nineteenth-century schism between public and domestic space.

Whereas the Renaissance house had been permeable, in the sense that it sheltered people and activities belonging to the family and to a wider scope in society, the nineteenth-century home was an impermeable structure, defensively regulating or completely repelling any activity and any person belonging to the outside world. This external environment was often portrayed as vile and ruthless because of its association with aggressive financial activity. Moreover, the Evangelical Movement ${ }^{5}$ further underlined the division of the home from a corrupt outside, a notion that permeated all circles in Victorian culture, including the academic and artistic world; in 1864, aesthetic critic John Ruskin, ${ }^{6}$ delivered the lecture "Lilies: Of Queens' Gardens," about the home and women's moralizing role in it. The following quote illustrates this dichotomy between the pure home and the corrupt world, a notion imbedded in Victorian culture:

This is the true nature of home-it is the place of Peace; the shelter, not only from all injury, but from all terror, doubt, and division. In so far as it is not this, it is not home: so far as these anxieties of the outer life penetrate into it, and the inconsistentlyminded, unknown, unloved, or hostile society of the outer world is allowed by either husband or wife to cross the threshold, it ceases to be home; it is then only a part of that outer world which you have roofed over [...] (Sesame and Lilies emphasis added)

However, as will become clear, the idea that the home could repel "terror and doubt" is highly questionable. The notion of a sheltered home was partly created as an attempt to generate a sense of ease, but analysis of Gothic fiction of the time proves just how much terror and doubt did circulate in the air, especially when connected to the 
household. Furthermore, the idea that this refuge would neutralize divisions is one that runs contrary to the main argument of this analysis. As mentioned previously, space was divided not only by separating the house from the world, but by partitioning areas within; spatial segregation, in fact, is the single most defining characteristic of the Victorian home. Moreover, in this excerpt Ruskin mentions Victorian nervousness about anxieties "penetrating" the house. In the same way in which the soul had to be assessed daily for any signs of corruption, the household and its members had to be constantly observed for any signs of evil that could manage to seep from the outside.

Victorian writers also attribute the preference for isolation in British domestic plans to the country's Northern location and climate: "the old English model, the growth of Northern soil, displays a character of domestic seclusion which seems to be more natural to the indoor habits of a Northern home" (Kerr 69). Furthermore, critics claimed that the plans of a home that favoured retirement reflected an insular identity. The notion that the isolated and autonomous nature of Britain as an island was the main force shaping domestic design is debatable, but in conjunction with other social elements, it did shape an insular household, with small "islands" composed by separate rooms and areas, along with occupants that withdrew into each of these havens:

of the characteristics of the planning of modern English houses, the most striking, when compared with the planning of former times, is its Multifariousness. Keeping pace with our more complicated ways of living, we have not only increased the number of rooms, in ordinary houses, but have assigned to each a special use [...] the plan must give Isolation to the several parts. (Stevens 47) 
A close look at Collins's novel and Riddell's story will show how the British home's compartmentalization, its dramatic separation from the outside, as well as its insular qualities are all addressed and magnified by the Gothic literature of the day. Furthermore, this analysis will suggest that spatial characteristics in the homes of these tales both manifest and foster excessive concerns over privacy, concealment and infiltration.

\section{The Myrtle Room and its Not-So-Dead Secret}

The Dead Secret (1857) was Collins's fourth novel; like The Woman in White, three years later, it offered classic sensational and Gothic elements, featuring the concealment of a shameful event within a chamber. On her deathbed, Mrs. Treverton orders her feeble-minded servant, Sarah Leeson, to disclose in a letter what has been kept from the former's husband, Captain Treverton: the infant Rosamond Treverton is in fact Sarah's illegitimate child, passed as Mrs. Treverton's own in order to retain the love of her husband and to save the real mother from disgrace. Instead of delivering the letter, Sarah flees, deciding to take the secret with her to the grave. However, because of her superstitious nature, Sarah is too afraid to disobey her mistress completely, so instead of destroying the letter, she hides it within the Myrtle Room, a disused chamber, hoping that it will never surface.

Wilkie Collins's The Dead Secret (1857) presents domestic spaces that are haunted by issues of privacy, concealment and secrecy. These three elements defined the landscape of the household at the time, shaping confined and secretive rooms, and stressing the containing and prohibitive roles of boundaries in their diverse architectural forms, in both the real households of the 
nineteenth century and their frightening counterparts in fiction. When Rosamond marries Leonard Frankland, the happy couple decides to move back to Rosamond's childhood home, Porthgenna Tower, but before reaching it, they stay in temporary lodgings. Miss Mowlem, the servant at the inn, is excessively curious about the young couple, rashly disregarding social considerations that existed between masters and servants, as in the following passage: "this observant spinster stole up stairs again, according to custom, to drink at the spring of knowledge through the key-hole channel of the drawing-room door [...]. 'She's actually sitting on his knee! Mother, did you ever sit on father's knee when you were married?"'(62). The servant goes as far as entering the drawing-room when Rosamond is kissing her husband, but her tactlessness proves to be too much: "Turning round instantly[...]. Mrs. Frankland, to her horror and indignation, confronted Miss Mowlem standing just inside the door [...]. 'You wretch! how (sic.) dare you come in without knocking at the door?"' (67). The offense is so severe that an irate Rosamond announces why they will be leaving: "Mr. Frankland says he won't have his rooms burst into, and his doors listened to by inquisitive women-and I say so too" (emphasis added 68). These passages clearly transmit the Victorian preoccupation with privacy and its translation into a domestic setting that sought to uphold an agreement of discretion among all its inhabitants.

A sense of spatial prudence was key in a home that had to be shared, by necessity, with servants. Kerr's quote in The Gentleman's House (1864) brilliantly exposes how the design of the house assured the marked division between the different classes:

The sleeping rooms of the domestics also have to be separated both internally and externally from those of the family, and 
indeed separately approached. The idea which underlies all is simply this: the family constitute one community. The servants another. Whatever may be their mutual regard and confidence, as dwellers under the same roof, each class is entitled to shut its door upon the other, and be alone. (emphasis added 68)

This fact clearly explains how the small home featured previously (Fig. 2) could incorporate separate staircases for each class, despite obvious limitations in size and budget. In 1880, another architect and critic, J. J. Stevenson, also identified the paramount consideration for privacy when planning the design of a home: "privacy is essential to our comfort, and to live in its fullness and variety our modern life, we require apartments appropriated to its various phases" (House Architecture Vol. II 3). Stevenson refers to the "modern" need to segregate space, as opposed to previous models that were not highly sensitive about separation. ${ }^{7}$

In Collins's novel, it becomes apparent that Miss Mowlem ignores a physical boundary - the door-employed for maintaining privacy, by peeping through the keyhole. The servant's affront threatens the delicate balance that exists in the household and that could be achieved by a simple shutting of a door, as Kerr proposes. Ignoring these architectural and social borders by listening through dangerous openings (such as keyholes), and worse yet, by "bursting into rooms" unannounced, are serious offenses in this spatially sensitive space where intimacy reigns supreme. After all, as German architect Herman Muthesius notes, "the Englishman plans the layout of his house without giving a thought to banquets and celebrations, but rather to fulfil all his residential needs as intimately as possible" (79).

Because of this high regard for domestic privacy, screening and hiding sights and events are main concerns in real and fictitious 
Victorian households. The positioning of furniture within a room responds to practical considerations, especially in bedrooms: "for planning a bedroom the rules are few and simple. A position should be provided for the bed, out of the way of the draughts between window, door, and fireplace; not with the object of excluding air, but rather that it may be admitted without danger of cold to the sleeper" (House Architecture 67). In The Dead Secret we see how, when Mrs. Frankland gives birth in her bedroom in the lodging house, special care is taken to ensure that the curtains of her four-poster bed are drawn at the foot of the bed closest to the fireplace, in order to avoid draughts. However, exceeding the practical uses, the placement of furniture within the Victorian bedroom also indicates the distress caused by the possibility of confidential scenes being overseen or heard by others. The narrator describes how the arrangement of Mrs. Frankland's bedroom is defensive in nature:

The bed was of the old-fashioned kind, with the customary four posts and the inevitable damask curtains. It projected from the wall into the middle of the room, in such a situation as to keep the door on the right hand of the person occupying it, the window on the left, and the fire-place opposite the foot of the bed. On the side nearest the window the curtains were open, while at the foot, and on the side near the door, they were closely drawn. By this arrangement, the interior of the bed was necessarily concealed from the view of any person first entering the room. (108)

The way in which furniture is employed assures the greatest measure of privacy possible for a mother and her newborn child; the drawing of the curtains on the side closest to the door acts as a spatial precaution that blocks unwanted strangers from witnessing and threatening what was perceived as an excessively feminine 
and intimate situation. When Dr. Orridge steps into this cocoonlike arrangement, his comments prove how claustrophobic and excessive (even by Victorian standards) it was: "Do you think you will be any the worse for a little freer circulation of air?" (108). His reaction shows how complicated it was to strike a balance between a wholesome home that admitted air and an unsafe one that allowed the entry of draughts or even worst threats to the family.

Privacy and concealment within the Victorian household, as well as in a representation of it in The Dead Secret, undoubtedly reflect norms of the time and function as anteroom to the central premise of the novel-secrecy-and to its numerous physical manifestations-doors, rooms, drawers, locks, bolts, and keys. Bolting doors logically goes hand in hand with the management of secrets in the novel. For instance, at the beginning of the novel, a dying Mrs. Treverton calls Sarah into her room, in order to write a letter telling Mr. Treverton the truth about Rosamond: "'Bolt the door' [...] 'Bolt the door. Let no one in, till I give you leave"'(13). The letter, as well as the room in which the dictation takes place, function as spaces of containment for the information. On the surface, writing the truth down saves the dying woman the trouble of a direct confrontation. At a deeper level, though, the letter, meant to disclose, is in reality a medium that anchors the secret; even though letters are meant for circulation, in this case, the document ironically holds and restricts the secret's free flow, hence suppressing the dangerous consequences that could result from sudden dissemination of the truth. ${ }^{8}$ One may argue that even Mrs. Treverton, the author of the letter, who is the person most interested in telling the secret, unconsciously or consciously chooses to place the information in the contained medium of a letter, instead of liberating the information by simply vocalizing it. 
112 Ilse M. Bussing, Sequestered Spaces and Defective Doors in...

From this point onwards, the secret is transferred from this particular bedroom to a less intimate one-the Myrtle Room-an unused chamber where Sarah Leeson hides her mistress's letter. And it is at this point in the novel that the relationship between secrecy and the architectural features of the home acquires the most relevance. When Rosamond arrives as the newly wed lady of Porthgenna Tower, she feels mysteriously drawn to the enigmatic room. Before reaching the secret itself, Rosamond and her husband Leonard must explore different compartments that are framed by the main one of the room. This effect of stripping off layers or penetrating a space that is organized in a sort of Russian-doll fashion, in order to reach an enigma, obviously adds to the suspense and highlights the issue of how boundaries are used within this nineteenth-century text to conceal and guard, much in the same way in which partitions within the Victorian home accomplished their containing and shielding roles.

In his article, Jerrold E. Hogle discusses the "tendency in Gothic crypts despite and because of their distance from groundings, to deepen themselves into enigmas both inaccessible and beckoning" (148). His engaging analysis of the dynamics of space of crypts coincides with the way I see secret space functioning in Collins's work; the numerous containers that hold the secret have everexpanding depths that keep drawing Rosamond in, with the promise of eventually reaching the secret. When she becomes her blind husband's eyes, it is through her meticulous description that we see the Myrtle Room and the different enclosures and barriers that it contains. She tells Leonard about the existence of two doors, apart from the one that they used to enter the chamber. His response about the door once again confirms how this feature and its connecting capacity generate a sense of uneasiness in a domestic setting valuing compartmentalization: "I don't like the idea of sitting here, and 
leaving you to open these doors by yourself" (264). As with any other opening into a room of the Victorian household, doors clearly generate feelings of insecurity.

A close look at domestic space in Collins's novel reveals a household whose obssession with discretion results in spatial considerations, valuing concealment and secrecy. Certain events and passages within the novel confirm the manifest relationship between architecture and social dynamics, as well as this link's reflection in the Gothic medium. Secrecy, the main Gothic motif in the novel, literally finds a dwelling in Porthgenna Tower, as Rosamond admits to her husband, Leonard: "now we are on the spot I feel as if we had driven the mystery into its last hiding-place. We are actually in the house that holds the Secret" (emphasis added 240). This admission initiates the search for the secret, a quest that makes Rosamond keep moving through the house to explore its different passages and rooms: "don't let us stop on this cold landing. Which way are we to go next?" (240). The answer to her question comes in a letter by a friend, who had "seen the transcribed Plan, and had ascertained that it really exhibited the positions of doors, staircases, and rooms, with the names attached to them" (251). The road to uncovering the secret, then, requires a meticulous study of the home's architectural and spatial mapping. In the same manner, the road to uncovering the domestic idiosyncrasies of the next Victorian home of fiction will require a thorough spatial exploration.

\section{The Restless Door at Ladlow Hall}

In The Dead Secret a heavy load from the family and home's past has been contained and suppressed, at least temporarily, within the enclosure of a room. "The Open Door" (1882), by J. H. 
114 Ilse M. Bussing, Sequestered Spaces and Defective Doors in...

Riddell, one of the most popular writers of her time, also presents the notion that a terrible act, this time a murder, was committed within a home, thus tainting the space within it. However, the variation presented by this tale, in relation to Collins's novel, is that the haunting secret is not hermetically locked within a room; in fact, the secret refuses to be contained when a door of a room will not shut until the murderer is discovered.

The narrator of Riddell's story is a clerk at an auctioneer's office, who hears from a colleague that Ladlow Hall has not been rented or sold because it is haunted: "'What is the matter?" (27), the protagonist asks, and his friend simply says "'A door that won't keep shut' [...] A door that will keep open, if you prefer that way of putting it"' (27). This analysis focuses on these fairly straightforward yet significant statements about the nature of the haunting by addressing the significance and role of doors within a Victorian domestic plan, as well as their intercommunicating but also blocking and obstructing functions. The premise here is that anxiety about infiltration and violation of privacy, as well as its spatial manifestation in the form of the door, shape Gothic tales such as Riddell's, where an open door is at the nucleus of the haunting.

Why is a door, rather, an open one, such a source of anxiety for the Victorians? What is so horrific about a door that refuses to remain shut in a nineteenth-century home? In order to answer these questions, we must first look at the basic function of a door, in a general context. J. J. Stevens comments on the following simple but essential notion about house planning throughout the ages:"During all the long ages through which the human race has passed one prominent feature of house planning has been the necessity of defence from attack by enemies [...] during all the Middle Ages this risk was at the 
door" (4). While the focus of this study is not on medieval domestic plans, several of the critics that I have addressed repeatedly draw comparisons between ancient defensive structures and the Victorian attitude towards withdrawn domesticity, reaffirming the saying that "an Englishman's house is his castle." Stevens also comments on the English need to retire: "when we settle to read or work, we prefer to be in a room where we can shut the door, uninterrupted by the traffic of the house" (115). Whereas plans in other European countries favoured features that connected the inside with the street, in the shape of balconies or terraces, (or the porch, popular in the United States,) Victorian households demanded spaces of seclusion, and the door was obviously the feature that sealed the occupant within these spaces. The assumption presented by Riddell's text is that a proper Victorian door should be able to be shut and remain that way as required, in order to procure the conditions of retirement that are essential to a British nineteenth-century lifestyle.

As soon as he steps into Ladlow Hall, the narrator notices that all doors, not just the haunted one, are significant features in the home: "I looked around me-doors-doors-doors. I had never before seen so many doors together all at once" (39). But his mission pertains to the single "haunted" door, as his employer explains, when he asks him to "stay in the house for a week; if at the end of that time you keep the door shut, locked, bolted or nailed up, telegraph for me, and I will go down-if not, come back" (29). We can gather from this statement that a sure sign that the abnormal has been "cured" is the door's ability to be shut and secured; moreover, the refusal of potential clients to let or buy the home unless this anomalous door and room have regained normality manifests the significance of enclosure in Victorian domesticity. 
In addition to acting as a main barrier to the outside, the door in the nineteenth-century home played a crucial role in relation to the encapsulation of rooms and in the dynamics of intercommunication. Muthesius addresses the uniqueness of this home's rooms: "the English room is a sort of cage, in which the inmate is entirely cut off from the next room" (Muthesius 79). Stevens embraces Muthesius's perspective on British domestic idiosyncrasies and their manifestation in the home: "with us, from our love of seclusion and retirement, each room must be isolated" (48). The seclusion of the room in Victorian households is a materialization of the need for privacy, which, as I have pointed out, was the reigning principle in domestic settings. Even the way in which the term "drawing-room" came into being sheds some light on this issue: "the term was derived from the 'with-drawing room' of the seventeenth century, usually situated near the bedrooms, where the ladies withdrew after dinner" (The English Terraced House 45, 46). One might argue that all rooms in Victorian homes were, in a way, "with-drawing rooms," in the best of cases creating feelings of safety and coziness, but in the worst, feelings of entrapment.

As with other aspects of the house, nineteenth-century critics set the example of continental homes as contrasting with English ones, remarking on the secluded nature of rooms in the nation's homes: "perhaps the most striking difference is the lack in England of communicating doors between the rooms, which means that the only access to a room is from a passage or a hall" (Muthesius 79). The hermetic quality of these rooms results in great part from the fact that the chambers may only be accessed through these lengthy passageways; these liminal transit zones connect, but also act as buffers, forcing people to pass through them before entering another room. As a Victorian architect remarks: 
the plan must give Isolation to the several parts. With our present habits we could not live in those old palaces, in which the only communication for a suite of twenty rooms, is by passing through each in succession. We must have separate communication to each room. This is a special characteristic of modern planning in England as compared with France, where the ordinary and regular entrance to one room is through another [...] With us, from our love of seclusion and retirement, each room must be isolated. A room loses its value to us if it is a passage to another. (Stevens 47,48)

This issue of limited and highly regulated intercommunication is yet another symptom of Victorian concern with seclusion. We can contrast the withdrawn nature of the British room with the more open French room below. While in the British plans the dining-room is not connected through a door to the drawing room or study, in the Parisian home one can clearly see the existence of connecting doors from day room to day room (from the Salon Chinois to the Salon de Jeu, for instance) without the need to step out into a corridor in order to move to another chamber, as in the British household. 
WOODHEYES PARK, MER MANCHESTER. By Ir: Hon ace dones, LSSO.

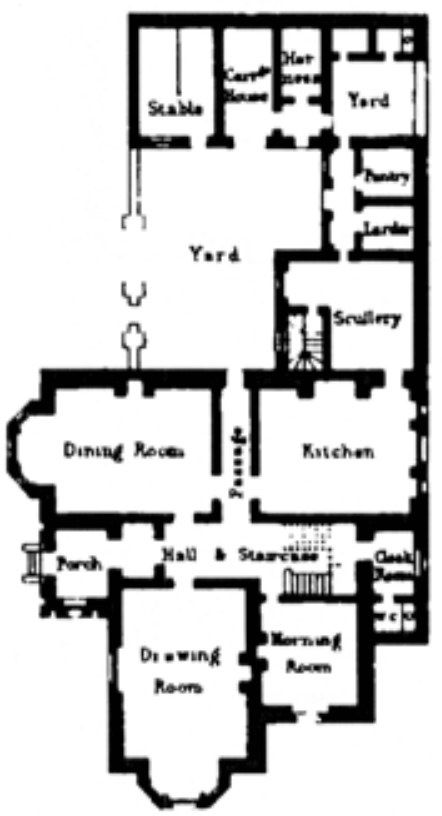

GROUND FLOOR.
Froen the Cinl Enoneer

Archatedis Journal

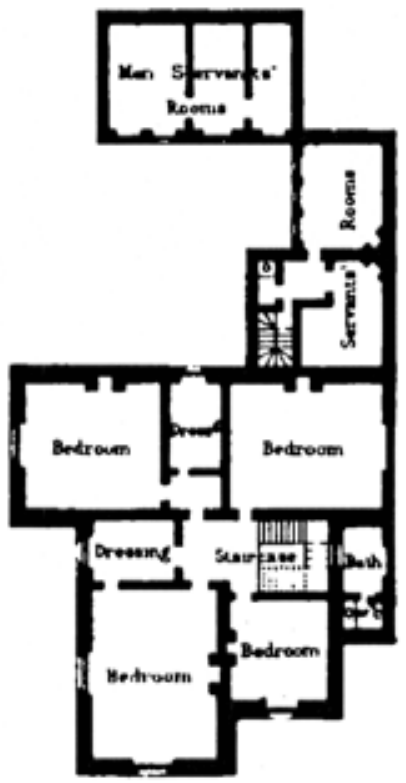

FIRST FLOOR.

Fig. 3. Limited communication in two British households, in Robert Kerr, The Gentleman's House $2^{\text {nd }}$ ed. (London: John Murray, 1865; print; plate 25). 
HOUSE IN PARIS.

How balyb"Aschicacure Prived

by M.M. Noles \& Conmble, 1860.

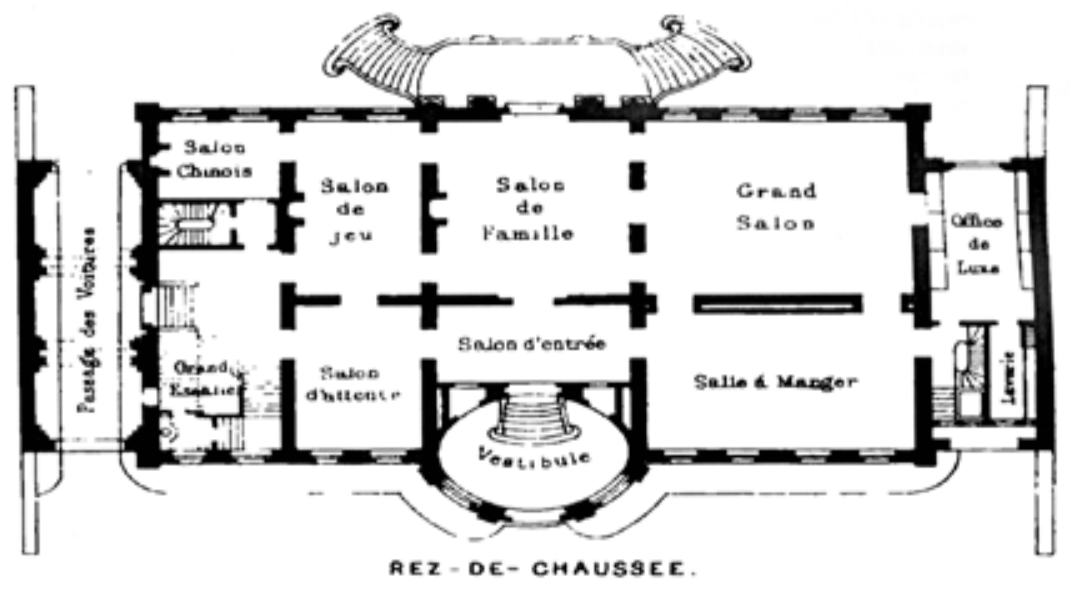

Fig. 4. Fluent intercommunication between rooms in a Parisian home, in Robert Kerr, The Gentleman's House $2^{\text {nd }} . e d$. (London: John Murray, 1865; print; plate 44).

All of these examples point to how sensitive Victorians were to the flow of different individuals through the household; the door was most certainly one of the key players in what could sometimes turn into a social game of hide-and-seek. Riddell's story transmits this sense of anxiety and friction between intercommunication and seclusion, by focusing on the feature that enabled these conditions to occur-the door.

In addition to an attack on privacy, an open door within a nineteenth-century home and in Riddell's story also points to the unsettling possibility of intrusion; not only does an open door signal that which could leak out of the room in the form of a private conversation or sight, but worse, that which could enter and somehow corrupt the interior of a room. The theme of infiltration is 
central in this story, beginning with the crime itself and continuing with the instances that the narrator experiences. The haunting has occurred because an intruder entered Lord Ladlow's room and killed him: "as in that room my uncle was murdered, they say the door will never remain shut till the murderer is discovered" (46). As the days pass in Ladlow Hall, the narrator attempts to solve the mystery of the crime with the help of one of the murdered man's descendants. The narrator soon realizes that in addition to the mysterious door not shutting, there is another problem at the hall of a more mundane nature: "though feeling convinced that no human agency did or could keep the door open, I was certain that some living person had means of access to the house which I could not discover" (50), since it is obvious that objects have been misplaced when the protagonist has not been present. The issue about an open door in Riddell's story highlights Victorian fears about the infiltration of threats that could dismantle the very core of the home.

The novel reveals one of the elements that could be particularly damaging to the home and domesticity, in the form of the intruder at Ladlow Hall. After the narrator realizes that the house has been broken into repeatedly, he decides to hide behind some curtains in order to discover the identity of the prowler:

the locked door opened-so suddenly, so silently, that I had barely time to draw back behind the curtain, before I saw a woman in the room. She went straight across to the other door and closed it, securing it as I saw with bolt and lock. Then, just glancing around, she made her way to the cabinet, and with a key she produced shot back the wards searching through the drawers. (53) 
The woman is the late Lord Ladlow's widow, and his murderer, and the objective of her search is the will that he had written, where he disinherited her. When the narrator apprehends her, "she fights like a wild cat, biting, kicking, and scratching" (139). The woman's unladylike behaviour and her criminal deeds clearly mark her as the antithesis of the "angel in the house" that so much of Victorian literature had propagated. But it is her fighting the narrator that stands out the most, providing a clue about the type of infiltrator that has caused the haunted door to remain open in Ladlow Hall.

In her study on Victorian women writers, Vanessa Dickerson points out how authors like Oliphant, Marryat and Riddell herself, "were in fact earning their own bread at a time when women were more openly challenging ideas of female submissiveness and economic powerlessness" (137), and that they had clearly identified ghost stories (such as "The Open Door") to be highly marketable. Furthermore, their fiction was "written in a climate of change and reform marked by such developments as the agitation of women's rights to education, employment, and suffrage; the passage of the married woman's property bills; and the rise of the New Woman" (133). The type of intruder in Riddell's story confronts a Victorian public with a woman who transcends a domestic setting where traditionally men, not women, were responsible for securing money and dealing in a ruthless business world. Riddell's fighting and kicking villainess does reinforce gender stereotypes of the time, by being classified as an evil woman who murders, plots and steals; however, at the same time, this aggressive woman signals the fear of a Victorian public who was sensing the emergence of a new and dangerous type of woman in the household.

In this story the open door signals abnormality-unless the crime is solved, the room will not return to its natural state as 
a sequestered space, and the door will not function properly, as a feature that enables seclusion. By looking at issues of intercommunication and blockage, we are able to comprehend the significant role of a single architectural feature in a setting that invested so much forethought in regulation of the internal flow of the home. This strict supervision of movement responded to the aforementioned primary condition of privacy, as well as to a great fear of infiltration, which in this story signals the appearance of a new type of woman in the home. But before the wild woman is finally tamed by the male narrator, the specter of the murdered husband manages to make one last appearance: "I saw, as in a momentary flash, that the door I had beheld locked stood wide-that there stood beside the table an awful figure, with uplifted hand" (54). This gesture reminds the characters, as well as the Victorian readers, that in this socio-historical context, even a deceased man still has the power over his wife, and that he may come back from the grave and demand things to return to "normal." Once his widow has been apprehended, things can in fact return to normal, and the door that signalled haunting may finally be shut, and the house can now be restored to its rightful male owner, the murdered man's nephew.

The spatial analysis of certain passages in The Dead Secret and "The Open Door" confirms the ineluctable link between architecture and the Victorian home's social essence. Moreover, this study proves how the social anxieties that derive from this dwelling's rigid spatial demarcation and strict observance of domesticity surface effortlessly into the Gothic medium. Whereas eighteenth-century Gothic favored ancient and exotic locales, nineteenth-century Gothic preferred locations closer to home, or literally at home. The Dead Secret's fixation with privacy, concealment, and secrecy, as well as "The Open Door's" 
obssession with compartmentalization and fear of infiltration can be traced on the home's very own composition, as if one were reading and interpreting its building plans. After analyzing these tales' architectural and highly symbolic features, one might safely say that literature is a space that can be penetrated and deciphered in the same way that buildings are texts that can be read and interpreted.

\section{Notes}

1. There is a strong tendency in Gothic studies revolving around the haunted-home trope to locate this literary phenomenon in time, specifically within the nineteenth century. In Gothic (London: Routledge,1996), Fred Botting mentions the shift of locale from the classical, eighteenth-century fiction to the nineteenth-century "homely Gothic." Byron and Punter, in The Gothic (Oxford: Blackwell Publishing, 2004) insist that a combination of socio-historical factors, especially the rise of domesticity, turned the spectral home into the protagonist of Gothic fiction: "Victorian Gothic is marked primarily by the domestication of Gothic figures, spaces and themes: horrors became explicitly located within the world of the contemporary reader" (26).

2. See Kate Ferguson Ellis, The Contested Castle: Gothic Novels and the Subversion of Domestic Ideology (Chicago: University of Illinois Press, 1989).

3. See Judith Flanders, Inside the Victorian Home: A Portrait of Domestic Life in Victorian England (New York: W.W. Norton \& Company, 2003) and John Tosh, A Man's Place: Masculinity and the Middle-Class Home in Victorian England (New Haven, Connecticut: Yale University Press, 1999), for a thorough analysis of gender and space in the Victorian home.

4. In order to fully understand how the nineteenth-century dwelling became a home, one must first acknowledge its medieval origins as a house and its evolution from that time onward. The medieval house was a hybrid site for family and numerous individuals, for personal as well as for business transactions. As such, this house sheltered various people and did not exclude those who were not members of the owner's family; employees, servants, apprentices, and frequent guests shared the same household with the owner and his immediate kin. The multifunctional nature of the house was clearly reflected in its internal design: "The public character of these houses is further underscored by the lack of separate rooms for these various activities. In most instances, the inhabitants lived, slept, and ate in large, open halls that 
accommodated different functions principally by the rearrangement of furniture" (Riley 11).

5. From the period of the 1730 s to the 1830 s, all denominations, including the most powerful one, the Church of England, were united behind one common front, the Evangelical Movement. See Hugh Mcleod's Religion and Society in England, 1850-1914 (London: MacMillan Press, 1996) for an in-depth look at this religious phenomenon.

6. Ruskin was raised in a strict Evangelical Anglican household, but his belief fluctuated from devout Evangelicalism to agnosticism and later on to the adoption of his unique version of Christianity. However, his academic writing always retained a strong Evangelical slant.

7. In "Housing and Privacy," in A History of Domestic Space (Vancouver, BC: UBC Press, 1999), Peter Ward discusses how "notions of privacy have always been contingent, 'constructed" (5). Furthermore, he points out how the "ideas about the nature of privacy have varied greatly from time to time, place to place, culture to culture" (5), thus explaining how the domestic setup within Britain could mutate in a matter of two centuries, from a relatively flexible setting, to a highly prohibitive structure, upholding privacy.

8. In Dead Secrets: Wilkie Collins and the Female Gothic (New Haven: Yale University Press, 1992), Tamar Heller comments on the feminist implications of the image of locking up and submerging texts written by women in Collins's works.

\section{References}

Botting, Fred. Gothic. London: Routledge, 1996.

Byron, Glennis and David Punter. The Gothic. Oxford: Blackwell Publishing, 2004.

Collins, Wilkie. The Dead Secret. (1857). New York: Dover Publications, Inc., 1979.

Cox, Jessica. "Representations of Illegitimacy in Wilkie Collins's Early Novels." Philological Quarterly 83.2 (2004): 147-69.

Dickerson, Vanessa. Keeping the Victorian House, A Collection of Essays. New York: Garland Publishers, Inc., 1995.

Ferguson Ellis, Kate. The Contested Castle: Gothic Novels and the Subversion of Domestic Ideology. Chicago: University of Illinois Press, 1989.

Flanders, Judith. Inside the Victorian Home: A Portrait of Domestic Life in Victorian England. New York: W.W. Norton \& Company, 2003. 
Heller, Tamar. Dead Secrets: Wilkie Collins and the Female Gothic. New Haven, Connecticut: Yale University Press, 1992.

Hogle, Jerrold E. "The Restless Labyrinth: Cryptonomy in the Gothic Novel”. Gothic Critical Concepts in Literary and Cultural Studies. Botting, Fred and Dale Townshend, eds. London: Routledge, 2004. 145-166.

Kerr, Robert. The Gentleman's House or How to Plan English Residences from the Parsonage to the Palace. $2^{\text {nd }}$ ed. London: John Murray, 1865.

Long, Helen. Victorian Houses and Their Details. Oxford: Architectural Press, 2002.

McLeod, Hugh. Religion and Society in England, 1850-1914. London: MacMillan Press, 1996.

Muthesius, Hermann. The English House. [Das englische haus] (1904-05). London: Crosby Lockwood Staples, 1979.

Muthesius, Stefan. The English Terraced House. New Haven, Connecticut: Yale University Press, 1982.

Riddell, J. H. “The Open Door." (1882). Weird Stories. London: Home and Van Thal, 1946. 28-58.

Riley, Terence. The Un-Private House. New York: The Museum of Modern Art, 1999.

Ruskin, John. “Lillies: Of Queens' Gardens.” Sesame and Lilies: Two Lectures Delivered at Manchester in 1864. New York: John Wiley \& Son, 1866. 76-119.

Stevens, J. J. House Architecture. London: MacMillan and Co., 1880.

Tosh, John. A Man's Place: Masculinity and the Middle-Class Home in Victorian England. New Haven, Connecticut: Yale University Press, 1999.

Ward, Peter. "Housing and Privacy." A History of Domestic Space. Vancouver, BC: UBC Press, 1999. 3-7.

[Received in 03/11/2011. Approved in 07/05/2012] 
